\title{
DIE BETEKENIS, FUNKSIES, BELONING EN VERANTWOORDELIKHEDE VAN DIE ONDERNEMER*.
}

\section{INLEIDING.}

Daar is vandag ' $n$ stortvloed van literatuur waarin die een aanval op die ander gemaak word op die stelsel van vrye onderneminge in die ekonomiese lewe. Beplanning of die geleide ekonomie word aangeprys terwyl die vrye huishouding of die "kapitalistiese" stelsel aangeval en veroordeel word.

'n Ernstige waarskuwing word tot ons hele gemeenskap gerig teen die stortvloed van sosialistiese en kommunistiese literatuur waarteenoor ons nie onverskillig mag staan nie. Schumpeter beweer bv. dat die kapitalistiese stelsel noodwendig tot ' $n$ val moet kom en dat die sosialisme in die plek van die kapitalisme sal kom. Teen so 'n fatalistiese houding moet stelling in-

*Hierdie artikel is'n kort samevatting van'n lesing wat die skrywer onlangs voor die Klerksdorpse Afrikaanse Sakekamer gehou het, en wat ook deur „Volkshandel" gepubliseer is. 
geneem word. Ons kan veral drie dinge doen om die sosialisering en kommunisering van ons vrye maatskaplike struktuur die hoof te bied.

Eerstens moet kennis versprei word van en waardering opgewek word vir ons vrye ekonomie d.w.s. vir die ondernemingsvorm en organisasie in ons ekonomiese lewe;

Tweedens moet die gebreke en geregverdigde kritiek wat daar wél teen die vrye verkeershuishouding bestaan, erken en alles in ons vermoë gedoen word om die gebreke uit die weg te ruim. Derdens moet die vrye ondernemer sy eie huis in orde bring.

\section{KENNIS VAN EN WAARDERING VIR ONS EKONOMIE.}

Onder die vrye volkshuishouding verstaan ons daardie stelsel waar die swaartepunt van die ekonomiese beslissinge berus by die indiwiduele ondernemings, ondanks die feit dat die owerheid op talle van punte in die ekonomiese lewe ingryp. Ons maatskaplike struktuur word dus veral gekenmerk deur die vrye ondernemer.

Dat daar teen die stelsel van vrye onderneming inderdaad wel besware ingebring kan word, word nie ontken nie. Maar dit beteken nog nie dat elke vrye sakeonderneming, waarin die ondernemer nog 'n belangrike rol speel, uit die bose is en onvoorwaardelik mee weggedoen moet word nie; of (waar die voorstelle op neerkom) dat die vrye ekonomie deur 'n sentraalgeleide stelsel vervang moet word nie. Tereg het minister S. Zijlstra dan ook onlangs daarop gewys dat die vrye georganiseerde produksie noodsaaklik is ,als de meest doelmatige vorm van een maatschappij met konsumptievrijheid en arbeidsvrijheid en voor het kunnen functionneren van de democratische staat." Prof. Van der Kooy voeg hieraan toe dat wie betoog dat daar op grond van Christelike of humanistiese solidariteit 'n maatskaplike omwenteling moet kom, uit die oog verloor dat die afskaffing van die ondernemersfunksie ' $n$ verbruikersrantsoenering, arbeidsdwang en 'n diktatuur sal meebring. Dit sou die laaste moontlikheid tot menslike solidariteit, wat reeds deur die kapitalisme in so 'n groot mate verwesenlik en gemeganiseer is, laat verlore gaan. Die mens is aan God verantwoording verskuldig en daarom het hy reg op vryheid-en hierdie vryheid mag hom nie deur' $n$ diktatuur en algehele beplanning ontneem word nie. Om die redes mag die vrye ondernemer in ons ekonomiese lewe dan ook nie verdwyn nie. 
DIE WANOPVATTINGE.

Dit wil my voorkom asof daar vandag in die breë kringe van ons samelewing ' $n$ algemene wanopvatting bestaan oor: eerstens,

die funksie wat die ondernemer verrig, tweedens,

die beloning (wat gewoonlik as wins bestempel word) wat die ondernemer ontvang; en derdens,

die algemene wanopvatting dat die groot moontlikste wins die enigste beginsel is wat ' $n$ rol speel by die handelinge van die ondernemer.

Die wanopvattinge spreek duidelik uit die bewering wat dikwels gehoor word, nl. dat die arbeiders, die tegnici, die ingenieurs, die „eintlike werk doen” terwyl die ondernemers op die een of ander slinkse wyse die wins inoes. Hierdie populêre wanopvattinge het in die Westerse wêreld gelei tot 'n groot mate van ontevredenheid oor die grondslae van ons maatskappy. Op sy beurt het hierdie ontevredenheid in 'n groot mate bygedra tot die sosialisering en kommunisering van ons maatskaplike struktuur.

DIE FUNKSIE WAT DIE ONDERNEMERS VERRIG.

Die gesonde onderneming is nie denkbaar sonder die ondernemingsfiguur nie, maar ook nie sonder die nodige kapitaalverskaffing en toegewyde arbeid nie.

In die vroeg-kapitalistiese tydperk is die entrepreneurs of ondernemers gesien as persone wat beheer verkry het deur inisiatief, maar tog 'n belangrike sosiale funksie verrig het deurdat hulle die prys van die produkte deur mededinging laag gehou het. Dit veronderstel volmaak-mededingende markvorm en die eenmansaak. Vandag word die eenmansaak nog aangetref maar word die ekonomiese lewe beheer deur die groot maatskappye waar eienaarskap en bestuurskap geskei is en die bestuur oor byna onbeperkte mag beskik. Die ondernemersfunksie word tans grootliks verrig deur gesalarieerde bestuurders, direkteure en besturende direkteure. Die aandeelhouers neem nie aktief deel aan die bestuur nie, en kan dus nie as die ondernemers gesien word nie.

Die leidende persone soos die President, Voorsitter van die Raad van Direkteure, Algemene Bestuurder, ens. verrig volgens Cole drie funksies t.w.: 
die organisasie van die afsonderlike eenhede; die uitbreiding van die gevestigde eenhede; en die aanwending van alle pogings om die gevestigde onderneming te laat aanpas by die gedurig veranderende omgewing.

Prof. dr. J. F. Haccoû verstaan onder die ondernemer die persoon wat sy insig, arbeidskrag en geldelike vermoë gesamentlik inspan en die risiko neem om uit die produksieproses 'n groter inkomste te verwerf as wat moontlik sou gewees het indien hy sy arbeidskrag en vermoë sou verhuur het.

Die ondernemer aanvaar nie slegs met die oog op groter inkome die onsekerheid van die produksieproses nie maar ook as gevolg van die lus om eie inisiatief te ontplooi, die gevoel van 'n ,eie baas" te wees, die eersug en die skeppingsdrang of die sosiale magsposisie. Tog is die winsmotief die middelpunt.

Die dra van persoonlike risiko's is onontbeerlik by die ondernemer wat ook eienaar is van die produksiemiddele. Ten Doesschate wys daarop dat die ondernemers behalwe produksiekoste en winste ook ander verantwoordelikhede moet ken, t.w. teenoor sy werknemers, afnemers en leweransiers en teenoor die belange van die nasionale gemeenskap wat nie in geld bereken kan word nie. Die beroepsondernemersleier kan die belange van die kapitaal, arbeiders en die maatskappy meer objektief beskou as die eienaar-ondernemer Die tendens tot losserwording van die band tussen eiendom en leiding van die onderneming in die hande van uitgesoekte vakkundige en geskoolde deskundiges, is goed te keur.

Behalwe die nastrewing van wins het die ondernemer die sosiale funksie van duursame bevordering van die welsyn van almal wat in die onderneming saamwerk. Die ondernemer het die ekonomiese funksie van nasionale welvaart en die sosiale funksie omdat die onderneming een van die selle is waaruit die samelewing opgebou is.

Uit bostaande is dit duidelik dat die kritiek dat die ondernemer heengaan met die wins terwyl die arbeiders, tegnici, ingenieurs en ander die werk doen, van alle waarheid ontbloot is. Op grond van die belangrikheid van die funksies wat die ondernemer moet verrig, is dit tog ook geregverdig dat hy 'n goeie beloning sal ontvang. 
DIE BELONING WAT DIE ONDERNEMER ONTVANG.

Dit is heeltemal foutief om vandag te beweer dat die ondernemer al die wins van ' $n$ bepaalde onderneming ontvang as beloning vir die funksies wat hy in die onderneming verrig.

Die term ondernemerswins stam uit 'n tyd waarin leiding en kapitaalverskaffing nog in die hande van een en dieselfde persoon gevestig was.

Naas die eenmansaak is daar vandag die maatskappy met baie aandeelhouers sodat daar nie ' $n$ ondernemerswins is nie maar 'n ondernemingswins wat an die hele onderneming met andeelhouers behoort. Die gehuurde bestuurder(s), die direkteure, ens., ontvang gewoonlik 'n kontraktuele loon (salaris) plus 'n deel van die ondernemingswins.

Met die opkoms en groei van die vakbondwese, die optrede van die Staat t.o.v. winsbelasting en sosiale versekering, die druk wat deur die openbare mening op ondernemers uitgeoefen word, die toepassing van die algemene sielkunde op die bedryfslewe, ens., het die ondernemers óf uit vrye wil óf as deel van hulle ondernemingsbeleid of deur magte van buite, daartoe oorgegaan om 'n deel van die wins uit te keer aan die werknemers en aandeelhouers. Die klagte dat die ondernemer dus met al die wins wegkom, kan miskien nog in die praktyk voorkom-maar dit is seker vandag, om bogenoemde redes, die uitsonderingsgevalle; dit kan feitlik alleen in die geval van die eenmansaak nog voorkom. In al die ander gevalle gaan die wins gedeeltelik na die kapitaalverskaffers en 'n deel ontvang die ondernemer(s) bo en behalwe hulle vaste salaris: Daarom is dit ook doelmatig om die beloning van die ondernemer nie as die wins te bestempel nie maar as die ondernemersbeloning. Verder ontvang die Staat in alle gevalle 'n deel van die wins en selfs die arbeiders ontvang soms'n deel.

\section{DIE MAKSIMUMWINSBEGINSELS.}

Die sosialiste beweer gewoonlik dat daar in die sosialistiese en kommunistiese stelsels gesorg word vir maksimum-behoeftebevrediging terwyl daar in die vrye ekonomie alleen gesorg word vir maksimumwinste. In die vrye ekonomie sal alleen daardie goedere voortgebring word waarvoor daar ' $n$ behoefte bestaan. Die ondernemers is deur die teoretiese ekonome voor die dertiger jare beskou dat hulle tog 'n belanrgike sosiale funksie verrig het deurdat die prys van hulle produkte en dienste as gevolg van onderlinge mededinging en die winsmotief laag gehou word. Die ekonomiese teorie het dus nog gestaan in die teken van die volmaak-mededingende 
markvorm waar die ondernemer nie sou kon waag om die prys van sy produk of diens hoër vas te stel as wat die mededingende mark hom sou toelaat nie.

Hierna het Chamberlin en Robinson daarop gewys dat elke produsent probeer om sy produk te onderskei van die van sy mededinger en dit gee dan aanleiding tot monopolisme en onvolmaakte mededinging. Omdat 'n produk verskil van ander maaksels, kan daar altyd 'n bepaalde hoeveelheid van verkoop word al verskil die prys met dié van sy mededingers.

Die teorie van die onvolmaakte mededinging kom daarop neer dat die ondernemer daartoe in staat is om maksimumwinste te verseker d.m.v. 'n beperkende produksiebeleid en 'n eie prysbeleid. Van die teorie kan afgelei word eerstens dat die ondernemer doelbewus sy produksieomvang beperk om sodoende hoër pryse vir sy produkte af te dwing en tweedens dat die ondernemer altyd daarop uit is en ook daartoe in staat is om maksimumwinste te maak ten koste van die verbruikers.

Hierdie teoretiese voorstelling word sterk in twyfel getrek omdat al sou die onderneming sy koste tot 'n groot mate met juistheid kan bepaal, bly sy vraag altyd 'n onsekere faktor, sodat van die gelykmaking van sy grenskoste en -inkomste in die praktyk heel selde iets tereg sal kom.

Hall en Hitch het bv. na 'n empiriese ondersoek tot die slotsom gekom dat die ondernemers in die praktyk nie in terme van die mooi teoretiese grensgedagtegang dink en werk nie.

Die ondernemer volg eenvoudige gedragsreëls en vra vir sy produk slegs sy kosprys plus 'n normale winsopslag. Verder streef hy na behoud van sy posisie op die mark en het hy 'n sekere neiging tot uitbreiding.

Die verskille in produk of prys is nie so groot of belangrik dat dit aan die onderneming die mate van beheer oor pryse en winste sal gee as wat die voorstanders van die onvolmaak-mededingende markvorm wil voorgee nie. Dit lyk eerder asof die tipiese toestand in die bedryfslewe vandag dié is waar die oligopolistiese element die hoofrol speel. In 'n sodanige mark kry ons ' $n$ klein aantal groot onderneminge en 'n aantal klein onderneminge wat dieselfde mark betree. Ons het dan te doen met die geval van die prysleier en prysnavolger. Al sou die onderneming (die prysleier of die prysnavolger) in staat wees om sy produkte te differensieer, moet ons die gedagte prysgee dat hulle in staat is om die pryse van hulle produkte so te beheer dat hulle oor onbeperkte monopoliemagte beskik en dus in staat is om monopoliewinste te maak. Eintlik kom die monopoliewinste in die oligopolistiese markvorm minder voor as wat algemeen aangeneem word. 
ERKENNING EN UITSKAKELING VAN DIE GEBREKE.

Die standpunt mag egter nie ingeneem word dat daar niks met ons huidige kapitalistiese vrye ekonomie verkeerd is nie. Die ondernemer kan op bepaalde markte ' $n$ magsposisie inneem waardeur die totstandgekome pryse aan die aanbieders van produksiefaktore geen redelike beloning, en aan die afnemers van die produk geen redelike voorsiening waarborg teen 'n redelike prys nie. 'n Kapitalistiese winsstrewe bekommer hom egter al te dikwels nie oor sodanige komplikasies nie. Dit streef sonder meer na wins en hou nie rekening daarmee dat pryse en inkomes hulle betekenis ontleen aan die menslike bestaan nie. Die ondernemer moet allereers, in die woorde van prof. Van der Kooy, gesien word as die draer van kulturele vooruitgang. En: kultuur is ons roeping om die natuur te onderwerp ter verwesenliking van ideale. Kultuur vereis ook tegniek, organisasie, politiek, stryd en mag. Vooruitgang van die kultuurvra na skeppende en uitvindende bedrywigheid, na onvoorspelbare en lotsbepalende inisiatiewe, maar ook aanpassing, handhawing, bewaring en eindelose herhaling. Dit is die fondament waarop die funksie van sowel die ondernemer as onderneming berus. Die leidende beginsel by die handeling van die ondernemer moet wees die ekonomiese, die geldelike winsstrewe. Maar ook die nie-op-geld-waardeerbare moet kragtens die ekonomiese beginsel in onderlinge harmonie en in die regte verband tot die maksimumwinsgewendheid wees. Die arbeid van die ondernemer is troue en eerlike arbeid, waarvan die bestaansmoontlikheid en die arbeidsvreugde van die medemens in 'n belangrike mate afhanklik is. Ek voel oortuig daarvan dat die vrye onderneming, mits die bogenoemde beginsels in ag geneem word, in staat is om die vrye ekonomie te laat voortleef wat op sy beurt weer sal sorg dat verbruiksvryheid, arbeidsvryheid, menslike eenheid en 'n nie-diktatoriale staatsvorm vir die mensheid behoue sal bly. Op die ondernemers rus daar dus 'n belangrike en verantwoordelike taak en ek wil die wens uitspreek dat elke ondernemer in ons land opnuut onder die indruk mag kom van sy veelvuldige pligte en verantwoordelikhede. Dit is noodsaaklik dat geen ondernemer met die bestaande toestande tevrede sal wees nie maar dat elkeen sy invloed sal gebruik om dit wat verkeerd is, reg te maak. Alleen langs dié weg kan die diktatoriale staatsvorm vermy word en die menslike vryheid gehandhaaf word.

B. VAN DEVENTER. 